\title{
An agent-based model of triple-negative breast cancer: the interplay between chemokine receptor CCR5 expression, cancer stem cells, and hypoxia
}

\author{
Kerri-Ann Norton $^{1 *}$ (D, Travis Wallace ${ }^{1}$, Niranjan B. Pandey ${ }^{1}$ and Aleksander S. Popel ${ }^{1,2}$
}

\begin{abstract}
Background: Triple-negative breast cancer lacks estrogen, progesterone, and HER2 receptors and is thus not possible to treat with targeted therapies for these receptors. Therefore, a greater understanding of triple-negative breast cancer is necessary for the treatment of this cancer type. In previous work from our laboratory, we found that chemokine ligand-receptor CCL5-CCR5 axis is important for the metastasis of human triple-negative breast cancer cell MDA-MB-231 to the lymph nodes and lungs, in a mouse xenograft model. We collected relevant experimental data from our and other laboratories for numbers of cancer stem cells, numbers of CCR5+ cells, and cell migration rates for different breast cancer cell lines and different experimental conditions.
\end{abstract}

Results: Using these experimental data we developed an in silico agent-based model of triple-negative breast cancer that considers surface receptor CCR5-high and CCR5-low cells and breast cancer stem cells, to predict the tumor growth rate and spatio-temporal distribution of cells in primary tumors. We find that high cancer stem cell percentages greatly increase tumor growth. We find that anti-stem cell treatment decreases tumor growth but may not lead to dormancy unless all stem cells get eliminated. We further find that hypoxia increases overall tumor growth and treatment with a CCR5 inhibitor maraviroc slightly decreases overall tumor growth. We also characterize 3D shapes of solid and invasive tumors using several shape metrics.

Conclusions: Breast cancer stem cells and CCR5+ cells affect the overall growth and morphology of breast tumors. In silico drug treatments demonstrate limited efficacy of incomplete inhibition of cancer stem cells after which tumor growth recurs, and CCR5 inhibition causes only a slight reduction in tumor growth.

Keywords: Systems biology, Computational model, Breast cancer, Tumor heterogeneity

\section{Background}

Breast cancer is a group of diseases that remain the most common malignancy afflicting women worldwide. Often targeted therapies focus on three main cellular receptors: estrogen, progesterone, and human epidermal growth factor receptor 2 (HER2) receptors. However, approximately $12 \%$ of all breast cancers lack these three targets [1]. Known as triple-negative breast cancer (TNBC) this subset is aggressive, metastatic, and difficult to treat. Lee

\footnotetext{
* Correspondence: Kerri.norton@gmail.com

'Department of Biomedical Engineering, School of Medicine, Johns Hopkins University, Baltimore, MD 21205, USA

Full list of author information is available at the end of the article
}

and colleagues developed an accelerated metastasis xenograft model that increased spontaneous metastasis of TNBC primary tumor to the lungs [2]. They found that TNBC tumors secrete chemokines that increase metastasis to the lungs and from these experiments they identified several potential targets for triple-negative breast cancer [3-5]. Specifically, they found that there is crosstalk between the primary tumor and the lymphatic endothelial cells in the primary tumor site, the lymph nodes, and lungs. TNBC cells secrete interleukin 6 (IL6) that becomes systemic and 'educates' lymphatic cells at the primary and metastatic sites. The 'educated' lymphatic cells then increase production of $\mathrm{C}-\mathrm{C}$ chemokine ligand 5 (CCL5) 
which increases pro-migratory signaling in the breast cancer cells through their CCR5 receptor. Other research has shown that mesenchymal stem cells secrete CCL5 promoting cancer cell motility, invasion, and metastasis [6]. Importantly, it has been shown that treatment with maraviroc, a CCR5 inhibitor approved by the FDA for HIV indication, reduced metastasis in lymph nodes and lungs $[3,7]$. Maraviroc was also shown to reduce bone metastases from prostate cancer in animal models [8]. Since CCR5 is an important receptor for TNBC proliferation, migration, and metastasis, we wanted to understand the distribution of CCR5 in triple-negative cell lines and then use this information in computational modeling to predict how these factors affect tumor growth.

Cancer stem cells have been found in many types of cancer [9] including breast [10], colorectal [11], neuroblastoma [12], and lung [13]. They have been associated with therapeutic resistance in breast cancer [14] and may lead to recurrence [15]. The most common markers for breast cancer stem cells are CD44, CD24 and ALDH1 [16]. Specifically, breast cancer stem cells have been associated with TNBC [17]. In estrogen receptor positive MCF-7 cell lines, CCL5 could increase the number of cancer stem cells in the tumor [18]. Thus, we wanted to understand the contributions of breast cancer stem cells in triple-negative breast cancer cell lines.

Computational modeling is a useful tool for studying cancer [19] and predicting tumor response to therapies $[20,21]$, for reviews see $[22,23]$; more specifically these methods can also be useful for understanding breast cancer, see review [24]. Early works investigating breast cancer using computational modeling include investigating the role of hypoxia and pressure in tumor necrosis [25], formation of pre-invasive tumor architectures [26], conditions leading to the disruption of normal breast acini formation [27, 28], patient calibrated breast cancer prediction [29], and predicting drug response [30]. More recently, computational models have been used to study ductal carcinoma in situ (DCIS) progression into invasive cancer [31], mechanical stress in breast cancer [32], interactions with the tumor microenvironment [33], and calcifications in the breast [34] . We have used agentbased models to investigate DCIS progression [35], avascular tumor growth [36], and tumor angiogenesis [37]. We now extend these approaches to understand the role of receptor heterogeneity in triple-negative breast cancer.

Cancer stem cells have also been the topic of a large number of computational models [38]. A series of models by Enderling and colleagues have investigated cancer stem cell dynamics in relation to radiotherapy resistance [39], directed migration [40], immunity [41], tumor dormancy [42], and senescence [43]. One interesting finding was that cell death could actually accelerate tumor growth due to the fact that it left space for stem cells to proliferate [44].
In particular, the inclusion of cancer stem cells in models were demonstrated to more accurately represent invasive behavior than those that only included non-stem cells [45]. Michor and colleagues have used computational models to study stem cell dynamics in pancreatic cancer [46], glioblastoma [47], and colorectal cancer [48]. Others have focused on cancer stem cells' ability to evade the immune system [49]. In the present study, we measure the fraction of cancer stem cells in a TNBC cell line and also assemble relevant data from other researchers; we then examine how these numbers affect tumor growth using computational modeling.

Tumor heterogeneity is an important aspect of breast cancer growth and has been the subject of many reviews [50-52]. Breast cancer heterogeneity is considered a major contributor to the difficulty in eradicating the disease including drug resistance [53-55]. In this paper, we examine receptor heterogeneity in triple-negative human breast cancer cells lines. The numbers of CCR5 cell surface receptors and molecular markers governing stemness were assembled from our and other laboratories. We then build an agent-based (rule-based) model of tumor growth for triple-negative breast cancer cells. We compare the growth rates and tumor morphology under different conditions, such as different stem cell and CCR5+ cell fractions, as well as drug treatment and hypoxia.

\section{Methods}

\section{In silico agent-based model}

The flow chart of the model is shown in Fig. 1. We initiated each simulation with 100 triple-negative breast cancer cells; the distributions of CCR5+ and stem cells matched those found in flow cytometry in triple-negative breast cancer cell lines. The initial 100 cells were placed in a cubic grid 100x100x80 voxels, each voxel $20 \times 20 \times 20 \mu \mathrm{m}$, maximum of one cell per voxel. The MDA-MB-231 cell diameter has been measured to be approximately 20 microns [56]. We assemble the data from the literature on percentages of CCR5+ cells in several breast cancer cell lines; they range from $1 \%$ to $14 \%$ under different treatments, including our data presented in the Additional file 1, Table 1. We have also found the percentages of cancer stems cells in different breast cancer cell lines range from less than $1 \%$ to $34 \%$, including our data presented in the Additional file 1, Table 2. All simulations were run for at least 8 different times and averaged.

In the initial simulations with MDA-MB-231 (in some instances referred to as MB231 for brevity) tumors, we used CCR5+ percentages as $6 \%$ and cancer stem cell percentages as $20 \%$ based on our experimental results. We then vary these numbers in the sensitivity analysis. For MB231 cells, we placed nineteen CCR5- stem cells, one CCR5+ stem cell, five CCR5+ progenitor cells, and seventy-five CCR5- progenitor cells on the grid. Then 


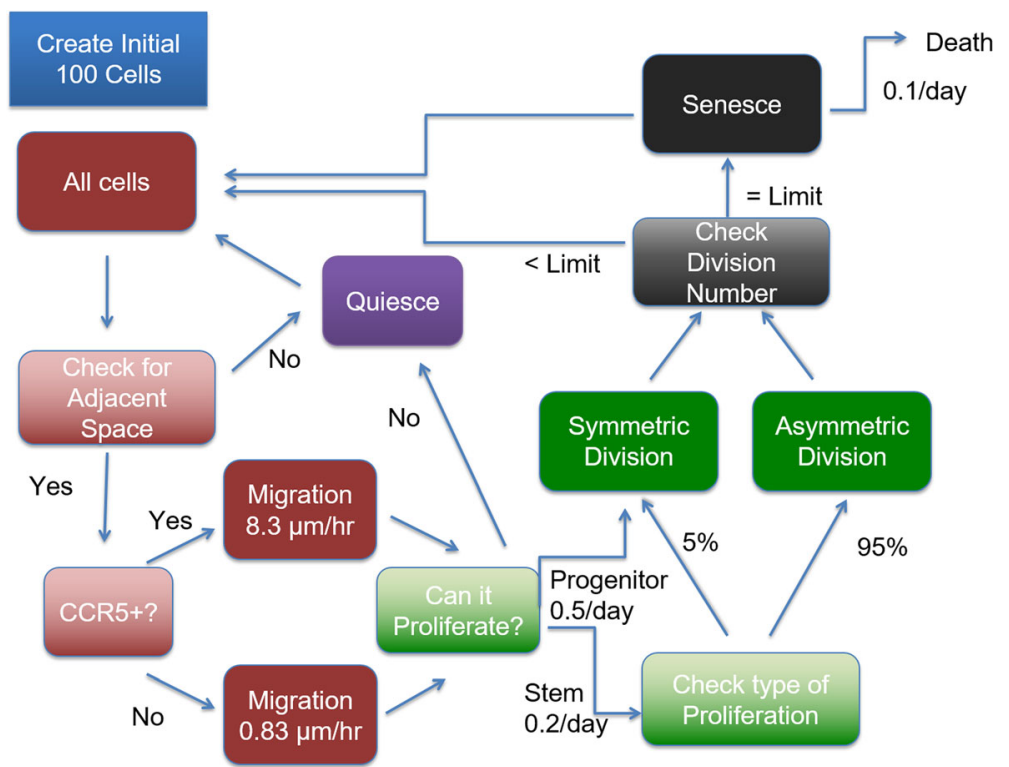

Fig. 1 Flowchart of the Agent-Based Model. The initial 100 cells are set up based on the flow cytometry results for the cell line MDA-MB-231 (MB231).

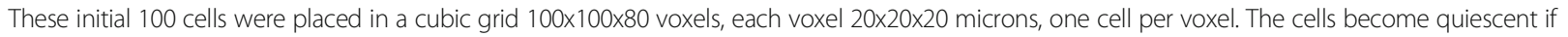
they have no adjacent space. The cells migrate based on their CCR5 expression levels. Stem cells can divide symmetrically or asymmetrically, whereas progenitor cells divide only symmetrically. If a progenitor cell has reached its division limit, it becomes senescent. Each day a senescent cell has a $10 \%$ chance of dying

the simulation ran through all the cells randomly. First, the neighboring positions (each voxel has 26 neighbors along $\mathrm{x}, \mathrm{y}, \mathrm{z}$ axes and diagonally, also known as the Moore neighborhood) of each cell were checked to determine whether there was a free space, if not the cell became quiescent. Each cell has a CCR5 receptor level that determines its migration speed. If a cell was CCR5 + , it was set to migrate faster than a CCR5- cell. Then it was determined whether the cell could proliferate; if the cell was a progenitor cell it must divide symmetrically into two progenitor cells, otherwise the stem cell could divide symmetrically into two stem cells or asymmetrically into a stem cell and a progenitor cell. If a progenitor cell had reached its division limit the cell became senescent. With each iteration a senescent cell had a $10 \%$ chance of dying. Once a cell dies, the voxel it occupied becomes available for other cells to proliferate or migrate into. The simulations run for 1080 days or until the tumor reaches 500,000 cells.

\section{Quiescence}

We randomly selected each cell and checked whether all of its neighboring spaces were occupied. If so, the cell became quiescent and was no longer able to proliferate or migrate. If one of the neighboring spaces became unoccupied the cell reverted back to its proliferative state.

Table 1 Percentages of CCR5+ Cells

\begin{tabular}{|c|c|c|c|}
\hline CCR5+ percent & Cell Line & Conditions & Reference \\
\hline $6.9 \%$ & Basal & CCR5 numbers & {$[7]$} \\
\hline $9 \%$ & MDA-MB-231 & CCL5 responsive cells & $"$ \\
\hline $3 \%$ & MDA-MB-231 + maraviroc & $"$ & $"$ \\
\hline $11 \%$ & MDA-MB-231 & $"$ & $"$ \\
\hline $1 \%$ & MDA-MB-231 + vicriviroc & $"$ & $"$ \\
\hline $13 \%$ & HS578T & $"$ & $"$ \\
\hline $5 \%$ & HS578T + maraviroc & $"$ & $"$ \\
\hline $14 \%$ & HS578T & $"$ & $"$ \\
\hline $5 \%$ & HS578T + vicriviroc & $"$ & $"$ \\
\hline $5-7 \%$ & SUM149 & CCR5 numbers & [82] \\
\hline $2-6 \%$ & MDA-MB-231 & CCR5 numbers & Our data \\
\hline
\end{tabular}


Table 2 Percentages of cancer stem cells

\begin{tabular}{llll}
\hline Stem cell \% & Cell line & Conditions & Reference \\
\hline $20 \%$ & SUM147 & control & {$[83]$} \\
$10 \%$ & SUM147 & treatment & {$[83]$} \\
$1-15 \%$ & MDA-MB-231 & & {$[84]$} \\
$1 \%$ & MDA-MB-231 & ALDH1 & {$[85]$} \\
$12 \%$ & MDA-MB-231 & Paclitaxel & $"$ \\
$1-13 \%$ & SUM159 & with/- Paclitaxel & $"$ \\
$6-24 \%$ & SUM149 & $n$ & {$[86]$} \\
$8-34 \%$ & SUM159 & $n$ & $"$ \\
$0.2 \%-12 \%$ & tumors & ALDH1 & {$[87]$} \\
$3.10 \%$ & MDA-MB-231 & & {$[88]$} \\
$2.70 \%$ & MDA-MB-435 & & $"$ \\
$\sim 0.5 \%$ & SUM225 & CD44 $^{+} /$CD24 $^{-} /$ESA $^{+}$ & {$[89]$} \\
$\sim 2.5 \%$ & SUM149 & CD44 $^{+} /$CD24 $^{-} /$ESA $^{+}$ & $"$ \\
$\sim 1.75 \%$ & SUM159 & CD44 $^{+} /$CD24 $^{-} /$ESA $^{+}$ & $"$ \\
$\sim 2.5 \%$ & SUM1315 & CD44 $^{+} /$CD24 $^{-} /$ESA $^{+}$ & $"$ \\
$\sim 2 \%$ & MDA-MB-231 & CD44 $^{+} /$CD24 $^{-} /$ESA $^{+}$ & $"$ \\
$9-20 \%$ & MDA-MB-231 & CD44 $^{+} /$CD24 $^{\prime}$ & Our data \\
\hline & & &
\end{tabular}

\section{Migration}

In this model migration was governed by the cells' CCR5 status and its microenvironment. Migration occurred as a random walk, where a neighboring space (Moore neighborhood) that was unoccupied was selected randomly and the cell was moved to that location. Based on reported observations of breast cancer cell migration rates, Table 3, we assumed that as reference values, if a cell was CCR5-, it could move one cell length per iteration $(0.83 \mu \mathrm{m}$ per hour or $20 \mu \mathrm{m}$ per $24 \mathrm{~h}$ equivalent to one iteration), the lower end of the migration rates from in vitro studies [36, 57, 58]. CCR5 + cells ranged from moving 2 cell lengths per iteration $(1.67 \mu \mathrm{m}$ per hour) to 20 cell lengths per iteration (16.67 $\mu \mathrm{m}$ per hour), based on the intermediate migration rates from in vitro studies [7, 59-61]. The high values were used for the more migratory hypoxic cells. If a MB231 cell was in a hypoxic microenvironment, it

Table 3 MB231 migration rates

\begin{tabular}{llll}
\hline MB231 Migration rate & Substrate & Conditions & Reference \\
\hline $0-40 \mu / \mathrm{hr}$ & GelMA hydrogels & $2 \mathrm{D}$ & {$[57]$} \\
$0.1-4 \mu / \mathrm{hr}$ & Matrigel & $3 \mathrm{D}$ & {$[58]$} \\
$12-48 \mu / \mathrm{hr}$ & Collagen & $2 \mathrm{D}$ & {$[60]$} \\
$8-18 \mu / \mathrm{hr}$ & - & channel & {$[59]$} \\
$38 \mu / \mathrm{hr}$ & Fibronectin & $2 \mathrm{D}$ & {$[90]$} \\
$7 \mu / \mathrm{hr}$ & Collagen & $3 \mathrm{D}$ & {$[91]$} \\
$3-9 \mu / \mathrm{hr}$ & Collagen & $3 \mathrm{D}$ & {$[92]$} \\
\hline
\end{tabular}

became more migratory [62]. Therefore in the model, a cell in a hypoxic zone could move three times as fast as a non-hypoxic cell each time it migrated [62].

\section{Proliferation}

Proliferation was governed by the cell's state, by whether it was a stem or a progenitor cell, and by its microenvironment. A stem cell could proliferate symmetrically to produce two stem cells or asymmetrically to produce a stem cell and a progenitor cell. A progenitor cell could only proliferate symmetrically to produce two progenitor cells. A stem cell had a range between $10 \%$ and $40 \%$ probability to proliferate each day and a symmetric division rate of $5 \%$ as done in previous models [36]. We assumed that as reference values a stem cell had a $20 \%$ probability of proliferating each day and a progenitor cell had a $50 \%$ probability of proliferating each day under normoxic conditions (36). Under hypoxic conditions the rates of proliferation were cut in half [62].

A cell could only proliferate if it had free adjacent space. Thus, the cell checked whether any spaces within the surrounding 26 grid spaces were unoccupied and chose a random free space to be the position of the new cell. A progenitor cell also checked whether it had reached its division limit before proliferating. If it had, it became senescent. A stem cell or progenitor cell had a $5 \%$ chance of producing a new CCR5+ cell each time it symmetrically proliferates. Once the cell had proliferated, its cycle number was increased by one and the new cell was assigned the same cycle number as its parent. The new cell was then placed on the grid.

\section{Senescence}

Stem cells could proliferate for the entire span of the simulation whereas progenitor cells could only proliferate 12 times before they became senescent, as done in previous models [36]. Once they were senescent they could no longer proliferate. Each day a senescent cell had a $10 \%$ probability of dying. Once a cell dies it is removed from the simulation.

\section{In silico anti-stem cell treatment}

Several drugs have been reported to selectively target breast cancer stem cells, such as salinomycin [10]. We assumed in the model that an anti-cancer stem cell drug would kill a percentage of cancer stem cells. We administer the drug in silico after day 150 . We apply the drug, with specific stem cell death rates between $50 \%$ to $90 \%$ efficacy, every 2 weeks for 98 days. We then track the growth of the tumor after treatment. 


\section{In silico maraviroc treatment}

Maraviroc is an FDA approved drug for HIV, a C-C chemokine receptor 5 (CCR5) inhibitor [63]. It has been shown to reduce metastasis to the lungs in a MB231 xenograft model in nude mice [3]. We assumed that maraviroc was able to reach all cells and was effective at shutting down the CCR5 enhanced migration. The therapeutic was applied throughout the entire simulation, which is not entirely realistic but would represent the most ideal case. Therefore, CCR5+ cells were considered inhibited and behaved as CCR5- cells, such that they could only move $0.83 \mu \mathrm{m}$ or one cell length every day in the presence of maraviroc.

\section{In silico hypoxia}

We assumed the vasculature was placed along the $y$-axis, assuming that this is the location of the normal tissue and the tissue was well oxygenated. Any cell greater than a distance of $200 \mu \mathrm{m}$ away from the vessels became hypoxic [64]. Experimentally, proliferation assays have shown that in vitro MB231 cells are half as proliferative under hypoxic conditions [62]. Migration assays have shown that in vitro hypoxic MB231 cells were also around 3 times as migratory as normoxic cells [62]. Thus, a cell would migrate three times as much in a hypoxic region than in a normoxic one. Specifically, a cell would search for an open space and move into this space and then it would search for a new open space and move. This random search would happen three times and is prevented from moving back to its original position. The numbers of CCR5+ cells increase under hypoxia [62] and we modeled the number of CCR5+ cells from MB231 cells as $25 \%$ based on the ranges from the literature [62]. Thus, a progenitor cell in a hypoxic region would produce a CCR $5+$ cell $25 \%$ of the time it proliferated, on average. We perform simulations to see how hypoxia affects the overall growth of the tumors.

\section{Model implementation}

The model proceeds in a stepwise fashion, in which the decisions made each day are based on the conditions and environment of the previous day. Each cell is confined to a single grid space (voxel) in a cellular automata (on-lattice) system and each cell is an automatous agent that makes decisions and performs actions based on its intrinsic parameters and its microenvironment in an agent-based system. The external boundary conditions of the grid are static, such that no cell can leave the grid. Once a cell hits a boundary it can only move in a direction within the grid space. The grid size is $4 \times 4 \times 4 \mathrm{~mm}$ with each cell having a diameter of $20 \mu \mathrm{m}$. The default number of initial stem CCR5-, stem CCR5+, progenitor CCR5+, and progenitor CCR5- cells are 19, 1, 6, and 74 respectively. The model was implemented in Matlab (MathWorks, Natick, MA).

\section{Shape metrics}

We calculated several metrics related to the 3D shape of the tumors: chord ratio, a variation of circularity [53], chord length [54], moment of inertia [53, 54], and fractal dimension [55, 65-67]. The chord ratio metric is calculated by the average $d_{c} / r_{s}$, where $r_{s}$ is the radius of a sphere with the same volume as the tumor and $d_{c}$ is the Euclidean distance from each of the cells on the periphery of the tumor and the tumor centroid. The chord length is the average radial distance/ the maximum radial distance, average $d_{c} / \max \left(d_{c}\right)$. The moment of inertia is defined as

$$
\sqrt{\left[\frac{1}{N} \sum_{i=1}^{N}\left(z_{i}-\mu\right) 2\right]}
$$

where $z_{i}$ are values of the radial distance function, $\mathrm{N}$ are the cells on the perimeter of the tumor, and $\mu$ is the mean radial distance. The moment of inertia is normalized by the mean radial distance. For both the chord ratio and moment of inertia, the larger the number the more finger-like the morphology. For the chord length, the smaller the number the more finger-like the morphology.

\section{Results}

In silico CCR5+ and stem cell percentage parameter space Triple-negative breast cancer cell lines were found to have varying CCR5+ percentages between 1 and 15\% (Table 1) and varying cancer stem cell percentages between 0 and $34 \%$ (Table 2). Therefore, to reflect the different experimental measurements and explore the entire ranges of these parameters reported by different researchers, we varied CCR5+ percentages between 3 and 13\% and the stem cell percentages in silico between 1 and 34\%. We find that at very low stem cell numbers the tumors initially grow but then shrink until there is just one stem cell left, Fig. 2. The percentage of stem cells has more effect on the total population but for intermediate percentages of cancer stem cells the CCR5+ percentage has more of an effect on the tumor growth, Fig. 2.

We show the parameter space of tumors at day 100 with varying cancer stem cell and CCR5+ percentages, Fig. 3a. The CCR5+ percentages range between $3 \%$ and $13 \%$. We show the stem cell percentages between $2 \%$ and $34 \%$ because for $1 \%$ there is only one cell. At high stem cell percentages, the tumors grow very quickly. The higher CCR5+ percentage with high stem cell percentages also has a more compact shape than the lower CCR5+ percentage. At lower cancer stem cell percentages, the tumors grow much slower and are more 

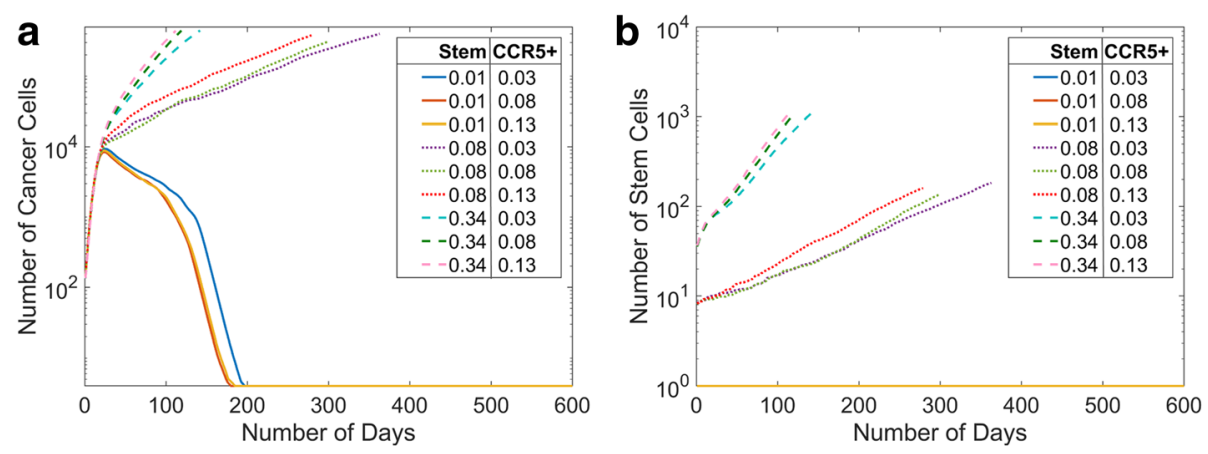

Fig. 2 Changes in the Initial Percentages of Cancer Stem Cells and CCR5+ Cells. We varied the initial cancer stem cell percentages from 1\% to 34\% and the initial CCR5+ percentages from 3\% to 13\%. We show the mean cell data over time (a), and the mean stem data over time (b). The percentages of cancer stem cells have a greater effect than the differences in CCR5+ cells

spread out. At intermediate values of CCR5+ and cancer stem cell percentages the tumor is of a medium size and has a compact morphology.

\section{At high CCR5+ percentages, the cancer stem cell percent governs the in silico morphology}

To examine the distributions of stem cells, CCR5+ cells, and progenitor cells we analyze slices from the 3D tumors. We show two examples with a high percentage of CCR5+ cells (13\%) and a low (2\%) initial percentage of stem cells, Fig. 3b, compared to a high initial percentage of stem cells (34\%), Fig. 3b. While CCR5+ cells (green cells) are about the same, the number of stem cells (red cells) are much smaller. Clearly the high percentage of initial stem cells results in a more compact tumor, whereas a low percentage of initial stem cells results in a disperse tumor made of several tumor "self-metastases." Thus, while having smaller stem cell percentages results in slower growing tumors, the tumors that result may be harder to excise completely.

\section{In silico anti-stem cell treatment decreases tumor size for MDA-MB-231 cells}

The previous simulations have examined the ranges of CCR5+ and cancer stem cells, for examining response to therapeutics we modeled MB231 cells with 6\% CCR5+ cells and $20 \%$ stem cells based on our and others experimental results, see Tables 1 and 2. Several drugs are reported to selectively target breast cancer stem cells, such as salinomycin [10]. We treated MB231 tumors in silico starting at day 150 with multiple doses of a drug that selectively targets and kills stem cells and assumed that it killed between $50 \%-90 \%$ of cancer stem cells, Fig. 4a,b. We investigate multiple doses of the same stem cell killing drug starting at day 150 and administering it every two weeks until day 248 . Under multiple doses with $75 \%$ or $90 \%$ efficacy the stem cells eventually die out and the tumors slowly die over 750 days, Fig. 4a,b. Once all the progenitor cells have reached their division limit they quickly die off. With only $50 \%$ efficacy, in some cases all the stem cells die off and in others some remain. If any stem cells remain, the stem cells eventually grow in numbers past the number they were at when they were originally killed off, Fig. 4b. In all three conditions, the tumors survive for hundreds of days even though they are dying off, Fig. 4a, thus even effective stem cell treatments will not quickly eliminate the tumors. We find that one dose killing $50-90 \%$ of stem cells merely slows down the growth of the tumor, data not shown. In one particular simulation, eliminating $90 \%$ of cancer stem cells caused the number of stem cells to drop to one and the tumor to remain dormant for some time but the number of stem cells eventually starts increasing again, data not shown. These results indicate that completely eliminating stem cells is necessary to eventually kill off the tumor and even if the treatment is effective at eliminating all stem cells, the regression of the tumor may be very slow.

\section{In silico maraviroc treatment slightly decreases tumor growth for MDA-MB-231 cells}

Maraviroc is an FDA-approved CCR5 inhibitor. We modeled maraviroc treatment by decreasing the migration rate of CCR5+ cells to be the same as CCR5- cells. Since the growth curves of the CCR5+ cells are more migratory, we hypothesized that maraviroc treatment might decrease the overall growth of the tumor due to an escape from spatial inhibition. We performed simulations of MB231 cells, Fig. 4c,d, under control and in silico maraviroc treatment conditions. We found that maraviroc treatment slows the growth of the MB231 tumors. We find that at day 300, which occurs after the initial growth phase but before the simulations have ended, the maraviroc treated MB231 tumors had fewer cells than control. The simulations also show that the day the tumor reaches 500,000 cells is somewhat higher 


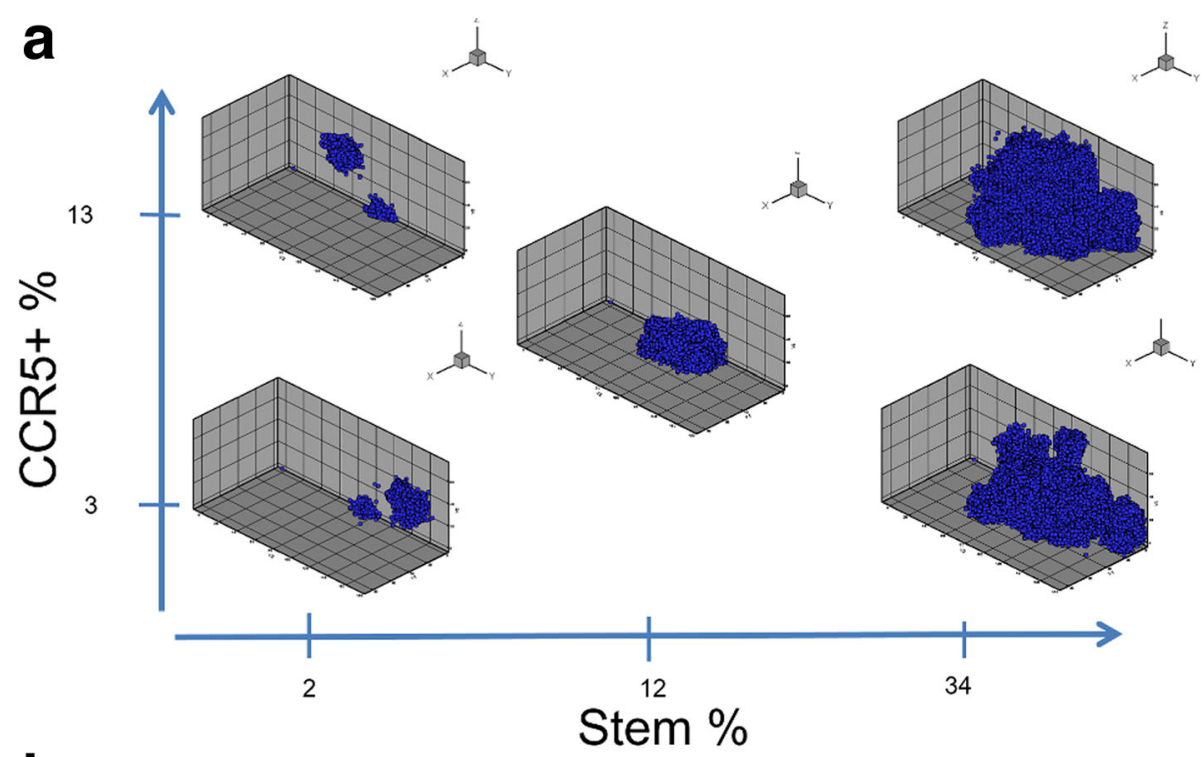

b
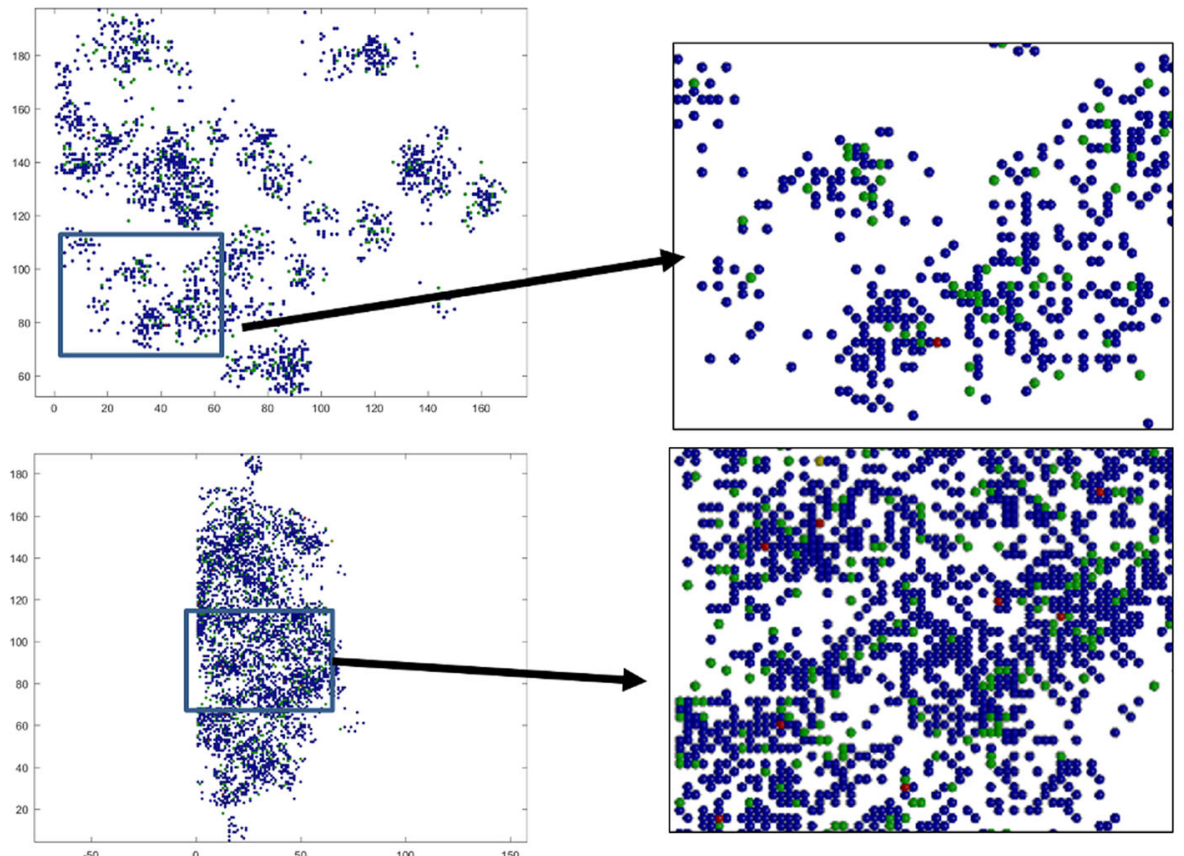

Fig. 3 3D Simulation Plots of the MB231 with Different Stem Cell and CCR5+ Populations. a Lower stem cell populations and higher CCR5+ percentages lead to more fingering morphologies. The plots are at day 100 . b The top tumor is a cross section of a tumor for simulation with $2 \%$ stem cells and $13 \%$ CCR5+ cells, with an inset. The bottom tumor is a cross section of a tumor for simulation with 34\% stem cells and 13\% CCR5+ cells, with an inset. With lower stem cell initial percentages, the tumor is made up of clusters of cells whereas the higher stem cell percentages result in a single larger tumor. Progenitor cells are shown in blue, CCR5 + cells in green, stem cells in red and both CCR5+ and stem cells in yellow

for maraviroc treated tumors than control, see below. All the tumors exhibit an exponential growth curve with an $\mathrm{R}^{2}$ value of 0.99 .

Hypoxia increases tumor growth for MDA-MB-231 tumors We included the development of hypoxic regions within the tumor and simulated the growth of MB231 tumors,
Fig. 4c,d. The growth of MB231 tumors is faster under hypoxic conditions. We also find that at day 300 , the hypoxic MB231 tumors had significantly more cells than control. The simulations also show that the length of time for the tumor to reach 500,000 cells is not significantly different for hypoxic tumors than for control tumors, see below. 

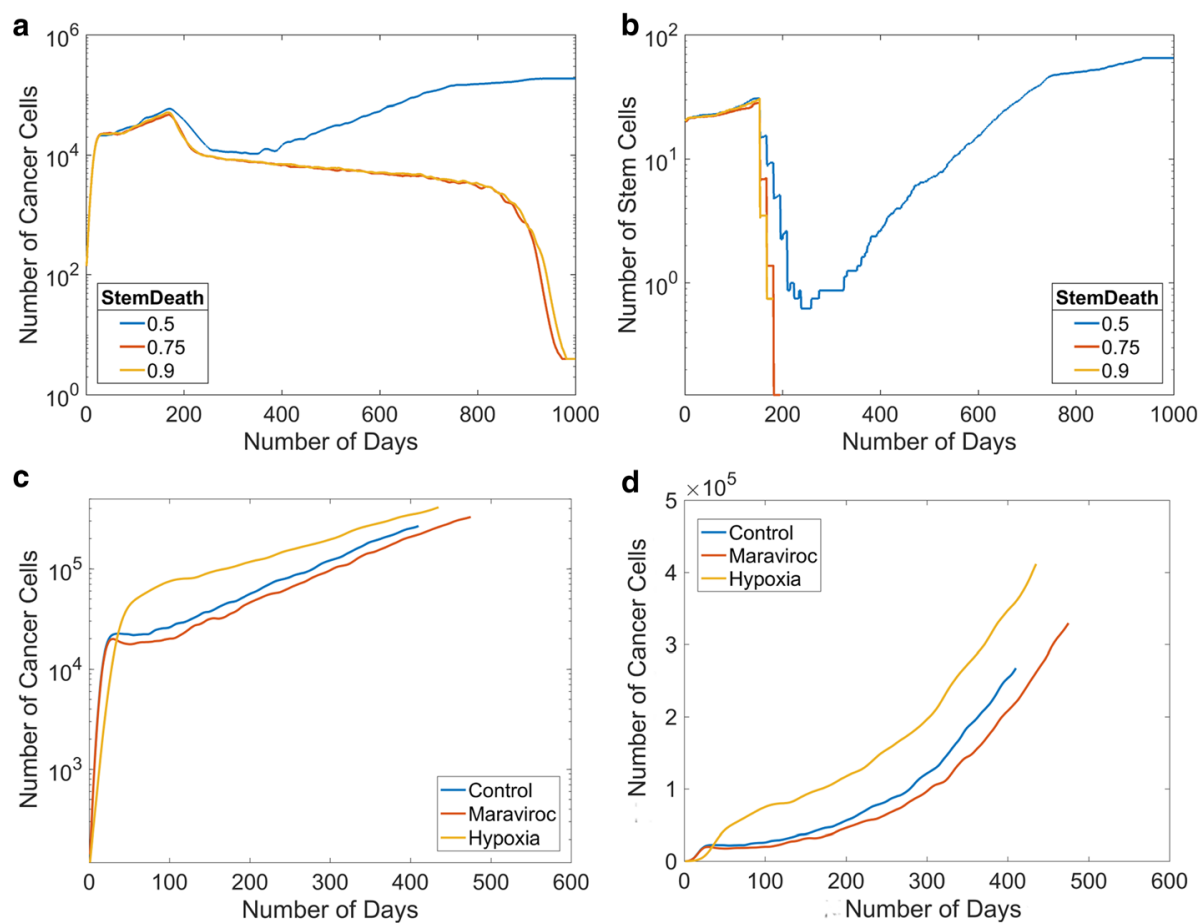

Fig. 4 Simulated tumor growth of MB231 cells under different conditions. a We investigate three doses of a drug treatment targeting cancer stem cells starting at day 150 with varying efficacy at killing cancer stem cells between 50\%-90\%. Plot of the mean total cell numbers over time after multiple doses of treatment. b Plot of the mean stem cell numbers over time after multiple doses of a drug treatment targeting cancer stem cells. c A semi-log plot comparison of MB231 primary tumors under control, hypoxic, and maraviroc conditions. d A plot of MB231 primary tumor under control, hypoxic, and maraviroc conditions

\section{In silico MDA-MB-231 tumors have solid and invasive 3D morphologies}

We find that even though the same initial parameters are used to simulate MB231 tumor growth, their ultimate morphologies vary between a solid, more compact tumor and an invasive, fingering tumor. An example 3D image of a solid MB231 morphology is shown in Fig. 5a. This tumor has a chord ratio metric of 1.18 and a moment of inertia of 0.23. In contrast, the MB231 tumors shown in Fig. 5b have finger-like projections, which is characteristic of invasive tumors. These fingers are due to isolated stem cells that are surrounded by progenitor cells which form due to migration. This tumor has a chord ratio metric of 1.36 and moment of inertia 0.35 . We evaluate the differences in metrics under different conditions below.

\section{Stem cell proliferation rate has a greater effect on tumor growth than migration rate}

In order to determine the effects of stem cell proliferation and CCR5+ cell migration on the overall tumor growth,

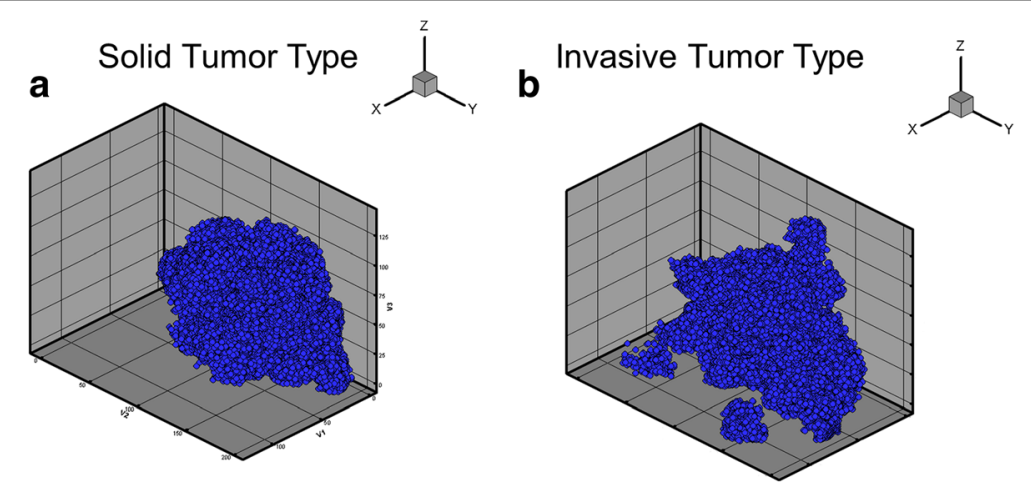

Fig. 5 3D Simulation Plots of the MB231 Solid and Invasive Morphologies. a An example of an MB231 tumor with a solid morphology. b An example of a tumor with an invasive morphology. There are finger-like projections coming out of the tumor making it a more invasive morphology 
we performed simulations varying the stem cell proliferation rate between 0.1 and 0.4 per day and the CCR5+ migration rate between 0.8 and $5.8 \mu \mathrm{m}$ per hour, in accordance with experimental data, see Tables 1-3. The mean cell numbers over time for each parameter condition are shown in Fig. 6a, and the mean numbers of stem cells over time in Fig. 6b. We do not show mean CCR5+ data over time because they follow the same trends as mean cell data. Low proliferation rates (0.1 per day) (PR) were associated with much slower tumor growth than higher proliferation rates. In contrast, changes in migration rates (MR) had less effect on tumor growth. We find similar trends for mean stem cell growth over time, Fig. 6b. Low proliferation rates slow stem cell growth over time and variation in migration rates have little effect.

\section{D morphology parameter space}

We display the 3D morphologies of the tumors under different proliferation rates $(\mathrm{PR})$ and migration rates (MR) at 300 days, Fig. 7. Migration appears to have more influence on the morphology and proliferation affects the numbers of cells. Tumors with higher MR have more finger-like projections, invasive bumps growing off of the tumor, than tumors with lower MR rates. Higher PR increases the numbers of cells and also contributes to a more solid-like morphology. The most finger-like tumor had low PR and high MR. The solid type morphologies are predicted to be less invasive, whereas the finger-like projections are predicted to be more invasive since they resemble invasive fronts seen in cancers.

To get a quantitative assessment of the effects of proliferation and migration we evaluated three shape metrics (chord length, moment of inertia, and chord ratio), and we display the metrics as contour plots for a range of PR and MR values, Fig. 8a. The lower the value of the chord length, the more finger-like the morphology. The higher the value of the chord ratio and moment of inertia the less compact the tumor shape is and thus they have more fingers and/or more prominent fingers. From these contour plots, it is clear that the most finger-like morphology is at high levels of migration and low levels of proliferation, whereas the tumor is more spherical at low migration and high proliferation rates.

\section{Contribution of maraviroc treatment and hypoxia to the invasive morphology of the tumor}

We examined four metrics: moment of inertia, day at which the tumor reaches 500,000 cells, chord ratio, and fractal dimension for MB231 tumors under control, maraviroc, and hypoxic conditions, Fig. 8b. We found that for the maraviroc treated tumors all metrics were statistically lower than for the normal condition for all metrics except for days using a one-tailed t-test, indicating a more compact morphology. We found that chord ratio was statistically higher for hypoxic than control conditions using a two-tailed t-test, indicating a more finger-like morphology. Also, hypoxic treated tumors took fewer days to reach 500,000 cells than the control tumors.

\section{Discussion}

High numbers of CCR5 receptors allow for an increased migratory behavior in tumors. We predicted that the increased migration might also increase tumor growth by opening up new space into which cells may divide. We found that the tumor growth was slightly slower by simulated maraviroc treatment, which was assumed to reduce the CCR5+ migration rate to normal. This result is qualitatively consistent with the studies from our laboratory showing that primary tumor growth was slightly lowered by maraviroc monotherapy treatment (but significantly inhibited by maraviroc in combination with other agents) (K. Jin, unpublished data) and observations by Lee et al. showing that the primary tumor was unchanged but the incidence of lung metastases was decreased [3]. We find that at lower migration rates, the decreased tumor growth does not occur (data not shown).
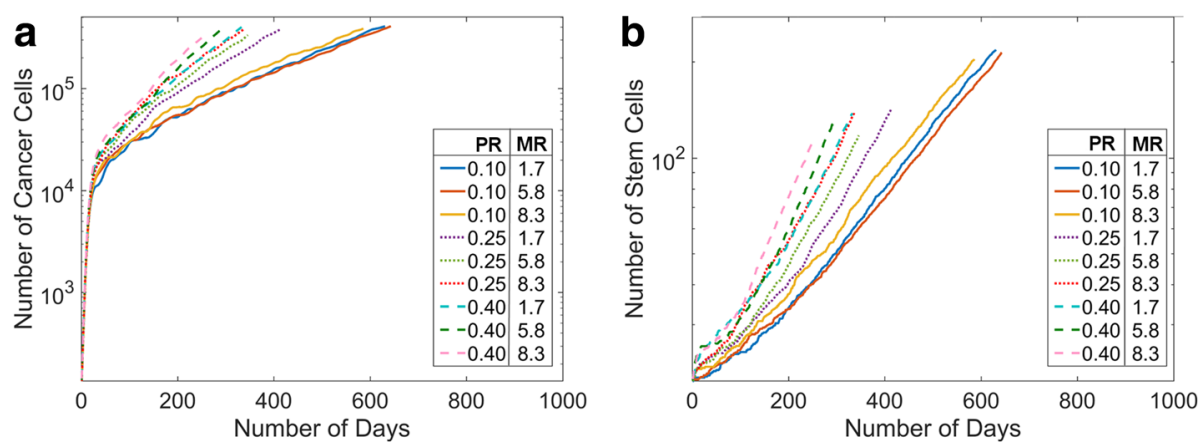

Fig. 6 Cell Growth under Different Stem Cell Proliferation and CCR5+ Migration Rates. a MB231 total cell growth under different proliferation and migration rates (PR, 1/day; MR, $\mu /$ h). Lower stem cell proliferation rates lead to slower growth. $\mathbf{b}$ Mean stem cell number under different proliferation and migration rates. Lower stem cell proliferation rates leads to fewer stem cells over time 


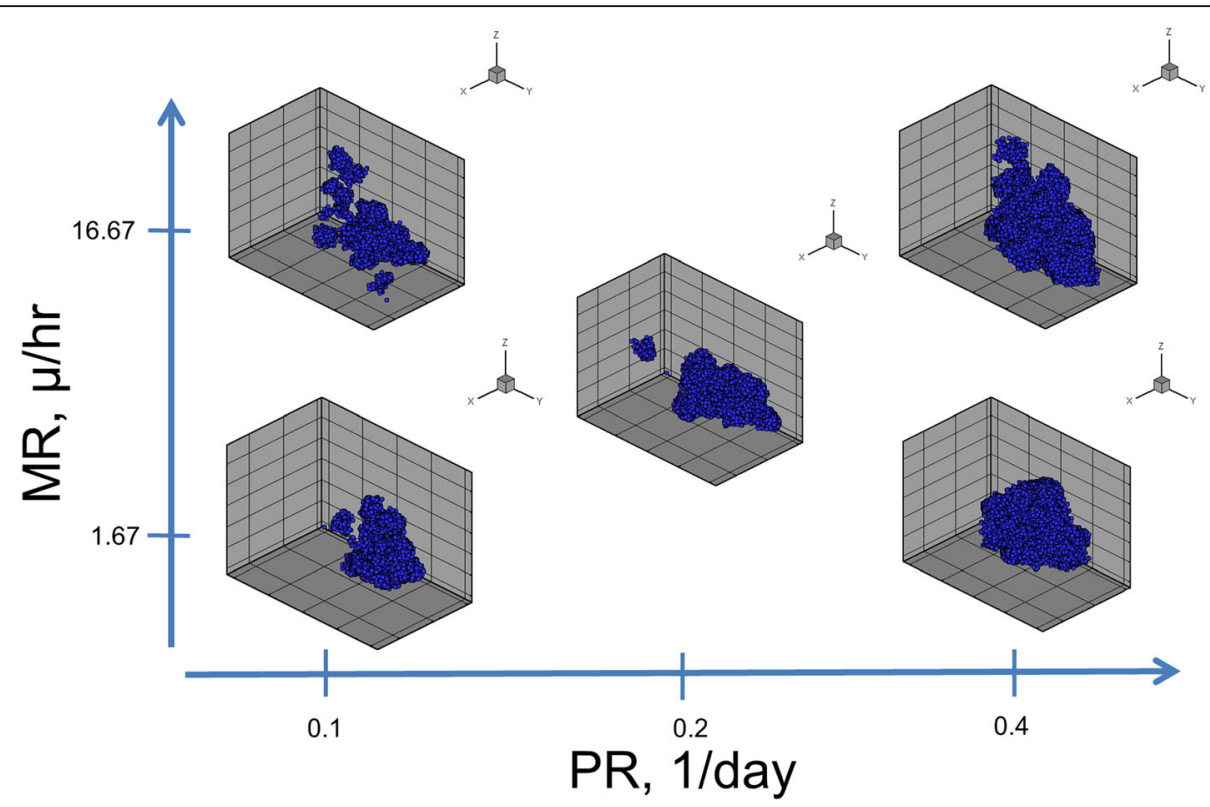

Fig. 7 3D Simulation Plots of the MB231 Tumors under Different Migration and Proliferation Rates. Lower proliferation rates (PR) and higher migration rates $(M R)$ lead to more fingering morphologies

Stem cell proliferation and CCR5+ migration rates were found to influence the tumor growth and morphology. However, despite the importance of both these attributes, the effects of proliferation were more significant. Lower initial cancer stem cell percentages can greatly lower the growth of the tumor. Lower stem cell proliferation rates decreased the total number of tumor cells, the number of CCR5+ cells, and the number of stem cells. Lower stem cell proliferation and higher CCR5+ migration rates were correlated with having a more finger-like morphology. This was observed qualitatively with the 3D morphologies and verified by the shape metrics. Each stem cell generates a group of progenitor cells that surround it. Therefore, if there are large amounts of stem cells these progenitor cell groups will overlap with one another, which would lead to a more solid-like morphology. When there are fewer stem cells these progenitor cells can form finger-like projections as they move away from the main tumor body. Thus, a lower stem cell proliferation rate can lead to a more finger-like morphology. The more migratory the cells, the more they can form finger-like projections as well due to a cell leaving a "trail" of cells behind them as they migrate. This is consistent with other models that showed that having fewer stem cells leads to a more invasive morphology $[40,45]$.

This computational model focuses on heterogeneity, specifically two relevant types of breast cancer heterogeneity are distributions of cancer stem cells and chemokine cell surface receptors $[68,69]$. We find that the distribution and number of stem cells greatly influences the morphology of the tumor, with lower numbers of stem cells leading to clusters of cells surrounding stem cells similar to 'self-metastases' [40, 42]. We find that the higher percentages of CCR5+ cells lead to more stem cell clusters due to the fact that migration leaves space for stem cells to migrate and proliferate. The heterogeneity of stem cells and CCR5+ cells leads to differences in the growth and morphology of the tumor. In other computational models, the migration rate of cells and cell turnover were found to contribute to the increased tumor heterogeneity [70].

We model a targeted cancer stem cell therapy, such as salinomycin [71], to see how effective they must be to eliminate or stall tumor progression. Targeting cancer stem cells has been a goal of several studies, for reviews see $[15,72]$, and several cancer stem cell drugs have been shown to significantly decrease mammosphere formation [73]. Multiple doses of a stem cell targeted drug that is greater than $50 \%$ effective eventually kills off all the stem cells which leads to a gradual regression of the tumor. We found that killing 50\% of cancer stem cells slows its progression but the tumor eventually recovers as long as a stem cell remains. Even if all but one stem cell is killed, tumor growth is only slowed for a time and then it starts growing again. Thus, while killing stem cells may seem like a therapeutic goal, these simulations suggest that suppressing a stem cell's symmetric division rate might be a more effective or an alternative strategy. These results also suggest that using other therapeutics, such as chemotherapy, along with the cancer stem cell targeted drug should be more effective at causing a quicker tumor regression. 


\section{a}

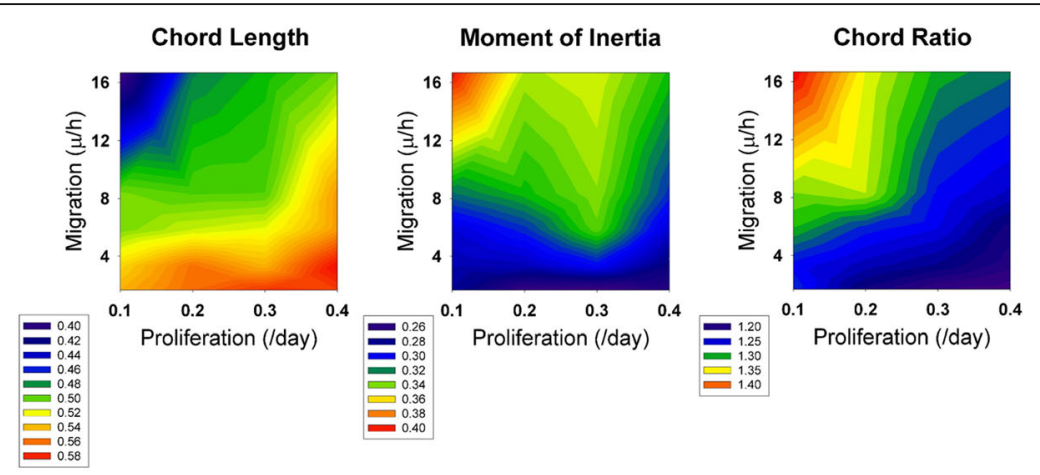

\section{b}
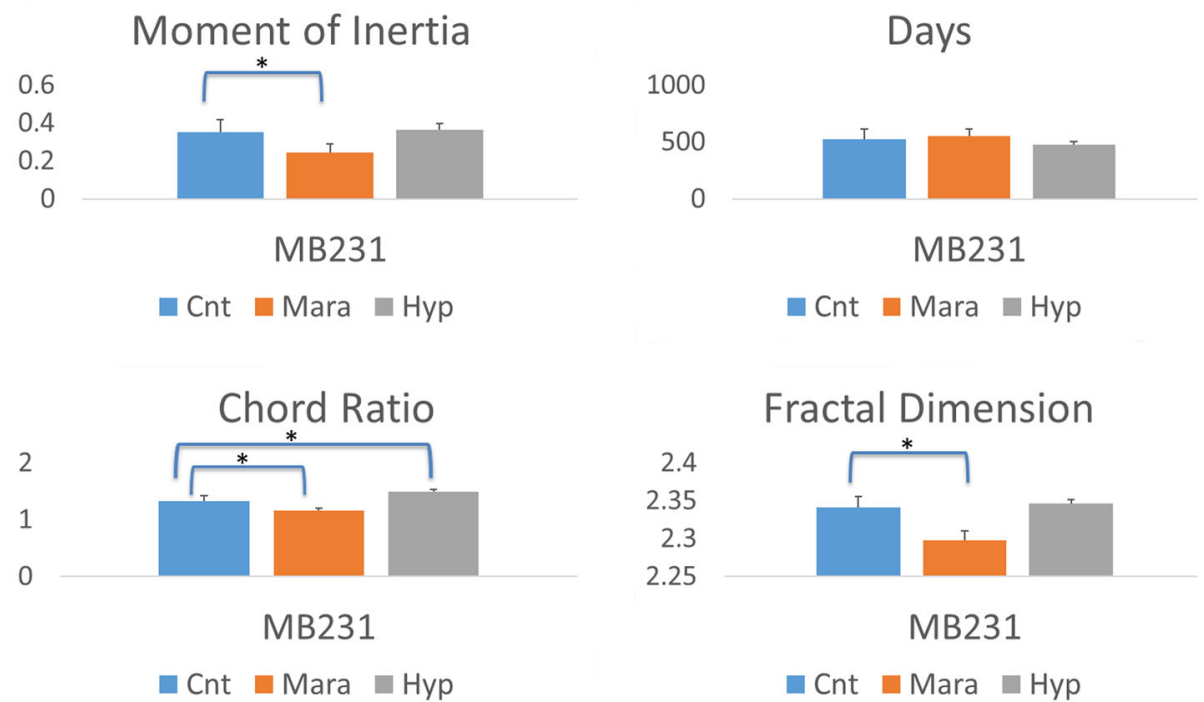

MB231

Fig. 8 Comparison of Shape Metrics of Tumors. a Contour plot of the chord length with increasing migration and proliferation rates. Contour plot of the moment of inertia with increasing migration and proliferation rates. Contour plot of the chord ratio metric with increasing migration and proliferation rates. All metrics show that the fingering morphology increases with increasing migration and decreasing proliferation. $\mathbf{b}$ The shape metrics indicates the invasiveness of the tumor morphology. We evaluate moment of inertia, days until end of simulation (500,000 cells), chord metric and fractal dimension. MB231 cells under maraviroc (Mara) treatment have statistically significant lower shape metric values than the parent cell lines (Cnt). MB231 cells under hypoxic conditions (Hyp) have statistically significant higher chord metrics than the parent cell lines (Cnt). Simulated maraviroc treated tumors all have statistically significant less invasive morphologies than their parent lines

Hypoxia was found to decrease proliferation and increase migration of cancer cells in vitro. Hypoxic tumors grew faster, possibly due to the free space left by migratory cells. Consistent with this hypothesis, we found that tumors with slower migration rates could actually decrease the tumor growth under hypoxic conditions, probably due to the decrease in proliferation (data not shown). Thus reducing migration rate may be an effective anti-tumor therapy. While the proliferation rate under hypoxia may be decreased, the ability for stem cells to symmetrically divide may be increased due to the free space left by tumor cell migration. Hypoxia has also been shown to reduce proliferation and increase migration in in vivo tumors [74]. Hypoxia causes cells to overexpress hypoxia-inducible factor 1 alpha (HIF1 $\alpha$ ) and vascular endothelial cell growth factor (VEGF) [75] which is associated with unfavorable prognosis in breast cancer patients $[76,77]$. These factors contribute to the angiogenic switch by recruiting new vasculature to the tumor [78]. Thus, while hypoxia before the angiogenic switch slows proliferation rates, the overexpression of HIF1 $\alpha$ and VEGF and the increase in migration leads to overall increases in tumor growth. Therefore, it would be important to combine angiogenesis and tumor growth models in breast cancer in future computational models.

Hypoxia was found to increase the invasive morphology of the tumors. This is most likely due to the fact that these tumors are less proliferative and more migratory, which was found to be more finger-like in the in silico parameter space. Cells are able to migrate more frequently, causing fingering morphologies, but without proliferating to create a solid morphology. This leads to 
hypoxic cells causing a more spread-out morphology and these tumors are more likely to be invasive and possibly more metastatic. This is consistent with many studies associating in vitro/in vivo hypoxia with breast cancer invasiveness [79] and metastasis [80, 81]. On the other hand, maraviroc treatment was found to decrease the invasive morphology of the in silico tumors. This is due to the reduction in migration leading to fewer migrating cells and fewer fingers.

Lastly, since the morphology of the tumors is an important aspect of the invasiveness of a tumor, shape metrics have been used to classify breast tumors from mammograms [53, 54]. Therefore, to relate our simulations to clinical results, we used several shape metrics to determine whether the tumors were more invasive or more solid. Chord length, chord ratio, moment of inertia and fractal dimension were all able to predict whether the tumor was invasive or solid. Circularity and fractal dimension were used to predict benign or malignant tendencies and were statistically significant [53]. Circularity is the mean radial distance of the tumor boundary divided by the standard deviation. In breast cancer patients, circularity of malignant breast tumors were 3.62 on average, whereas benign tumors had an average value of 5.57 [53]. The fractal dimensions of the boundary of breast tumors in cross section were 1.25 for benign and 1.6 for malignant tumors [67], for brain tumors the fractal dimensions of the tumor surface were between 2 and 3 depending on the image processing method [65]. When applied to our simulated tumors, these metrics yielded circularity values between 2.6 and 4.0 and fractal dimension values between 2.3 and 2.36. According to this, all of the tumors would be predicted to be malignant, which is consistent with MB231 tumors being metastatic.

There are several limitations of this model. First of all, we examine tumor growth before the angiogenic switch. This allows us to understand the progression of early tumor but it will need to be expanded upon to understand the continued growth of the tumor, tumor vasculature, and metastasis. Another limitation of the model is that it does not take into account the complex anisotropic structure of the host mammary tissue with its branching network of mammary ducts; this background could have an effect on the shape of the growing breast tumor. This issue deserves an investigation in future models. Another limitation is that the model uses triple-negative breast cancer cell lines for parameter fittings. While this allows direct comparison between the more and less metastatic cell lines, it may not be generalizable to other types of breast cancer or solid tumors. This model focuses on primary tumor growth but in future directions we will examine breast cancer metastasis to other organs such as the lung, lymph nodes and bone.

\section{Conclusions}

In conclusion, we have used experimental and computational techniques to examine the effects of migration of CCR5+ cancer cells, stem cell proliferation, and hypoxia on the growth and progression of triple-negative breast tumors. The major conclusions of our computational model are that 1) stem cell percentages and proliferation rates have a greater effect on tumor growth than CCR5+ percentages and migration rates, 2) treatments that do not eliminate all stem cells cause tumor reduction but the tumors eventually relapse, 3) maraviroc treatment slightly decreases tumor size, but the effect is not as pronounced as the effects of hypoxia or anti-stem cell treatment, 4) hypoxia accelerates tumor growth, 5) 3D finger-like tumor morphologies occur at higher migration and lower proliferation rates. We show that there is an important interplay between cancer stem cells, cancer CCR5 + cells, hypoxia, and therapies that can affect tumor growth and invasion. The model provides a framework for analyzing the effects of tumor cellular heterogeneity and pharmacodynamics; building on this development future studies should include other cell types in the tumor microenvironment, e.g., tumor-associated fibroblasts, and immune cells such as macrophages and $\mathrm{T}$ cells, as well as expand on the pharmaceutical agents that interfere with different cellular processes.

\section{Additional file}

Additional file 1: This includes a table with the parameters used in the model, as well as the experimental measurements of CCR5 and stem cells in MB231 cells using flow cytometry, migration assays of hypoxic and normoxic MB231 cells. (DOCX $973 \mathrm{~kb})$

\section{Abbreviations}

CCL5: Chemokine ligand 5; CCR5: Chemokine receptor 5; DCIS: Ductal carcinoma in situ; HER2: Human epidermal growth factor receptor 2;

HIF1a: Hypoxia-inducible factor 1 alpha; HIV: Human immunodeficiency virus; IL6: Interleukin 6; MB321: MDA-MB-231; MR: Migration rate; PR: Proliferation rate; TNBC: Triple negative breast cancer; VEGF: Vascular endothelial growth factor

\section{Acknowledgements}

We thank Adam Mirando for his comments on the manuscript.

\section{Funding}

This work was supported by the National Institutes of Health grant R01 CA138264, R01 CA196701 (ASP) and an American Cancer Society postdoctoral fellowship PF-13-174-01-CSM (KN). The funding body had no role in the design of the study, collection, analysis, and interpretation of data or in writing the manuscript.

\section{Availability of data and materials}

The codes for generating the data are available upon reasonable request on our website http://pages.jh.edu/ apopel/.

\section{Authors' contributions}

$\mathrm{KN}$ contributed to design of in silico and in vitro experiments, coding, acquisition of data, analyzing data, and a major contributor in writing the manuscript. TW contributed to conducting the flow cytometry experiments and analyzing data. NBP contributed to design of in vitro experiments, 
acquisition of in vitro data and analyzing data. ASP contributed to the design of experiments and in writing the manuscript. All authors read and approved the final manuscript.

\section{Ethics approval and consent to participate}

Not applicable.

\section{Consent for publication}

Not applicable.

\section{Competing interests}

The authors declare that they have no competing interests.

\section{Publisher's Note}

Springer Nature remains neutral with regard to jurisdictional claims in published maps and institutional affiliations.

\section{Author details}

'Department of Biomedical Engineering, School of Medicine, Johns Hopkins University, Baltimore, MD 21205, USA. ${ }^{2}$ Department of Oncology and the Sidney Kimmel Comprehensive Cancer Center, School of Medicine, Johns Hopkins University, Baltimore, USA

Received: 30 December 2016 Accepted: 30 June 2017 Published online: 11 July 2017

\section{References}

1. American Cancer Society. Breast Cancer Facts \& Figures 2015-2016. Atlanta: American: Cancer Society, Inc; 2015

2. Lee E, Pandey NB, Popel AS. Pre-treatment of mice with tumor-conditioned media accelerates metastasis to lymph nodes and lungs: a new spontaneous breast cancer metastasis model. Clin Exp metastasis. 2014; 31(1):67-79. PubMed PMID: 23963763. Pubmed Central PMCID: 3947147

3. Lee E, Fertig EJ, Jin K, Sukumar S, Pandey NB, Popel AS. Breast cancer cells condition lymphatic endothelial cells within pre-metastatic niches to promote metastasis. Nat Commun. 2014;5:4715. PubMed PMID: 25178650. Pubmed Central PMCID: 4351998

4. Lee E, Pandey NB, Popel AS. Lymphatic endothelial cells support tumor growth in breast cancer. Sci Rep. 2014:4:5853. PubMed PMID: 25068296

5. Lee E, Pandey NB, Popel AS. Crosstalk between cancer cells and blood endothelial and lymphatic endothelial cells in tumour and organ microenvironment. Expert Rev Mol Med. 2015:17:e3. PubMed PMID: 25634527. Pubmed Central PMCID: 4352000

6. Karnoub AE, Dash AB, Vo AP, Sullivan A, Brooks MW, Bell GW, et al. Mesenchymal stem cells within tumour stroma promote breast cancer metastasis. Nature. 2007:449(7162):557-63. PubMed PMID: 17914389

7. Velasco-Velazquez M, Jiao X, De La Fuente M, Pestell TG, Ertel A, Lisanti MP, et al. CCR5 antagonist blocks metastasis of basal breast cancer cells. Cancer Res. 2012;72(15):3839-50. PubMed PMID: 22637726

8. Sicoli D, Jiao X, Ju X, Velasco-Velazquez M, Ertel A, Addya S, et al. CCR5 receptor antagonists block metastasis to bone of $\mathrm{V}$-Src oncogenetransformed metastatic prostate cancer cell lines. Cancer Res. 2014;74(23): 7103-14. PubMed PMID: 25452256. Pubmed Central PMCID: 4294544

9. Vermeulen L. De Sousa e Melo F, Richel DJ, Medema JP. The developing cancer stem-cell model: clinical challenges and opportunities. Lancet Oncol. 2012;13(2):e83-9. PubMed PMID: 22300863

10. Velasco-Velazquez MA, Homsi N, De La Fuente M, Pestell RG. Breast cancer stem cells. Int J Biochem Cell Biol. 2012;44(4):573-7. PubMed PMID: 22249027. Pubmed Central PMCID: 3294043

11. Fanali C, Lucchetti D, Farina M, Corbi M, Cufino V, Cittadini A, et al. Cancer stem cells in colorectal cancer from pathogenesis to therapy: controversies and perspectives. World J Gastroenterol. 2014;20(4):923-42. PubMed PMID: 24574766. Pubmed Central PMCID: 3921545

12. Garner EF, Beierle EA. Cancer Stem Cells and Their Interaction with the Tumor Microenvironment in Neuroblastoma. Cancers (Basel). 2015;8(1):5. PubMed PMID: 26729169. Pubmed Central PMCID: 4728452

13. Lundin A, Driscoll B. Lung cancer stem cells: progress and prospects. Cancer Lett. 2013·338(1):89-93. PubMed PMID: 22906416. Pubmed Central PMCID: 3686996

14. Liu S, Cong Y, Wang D, Sun Y, Deng L, Liu Y, et al. Breast cancer stem cells transition between epithelial and mesenchymal states reflective of their normal counterparts. Stem Cell Rep. 2014;2(1):78-91. PubMed PMID: 24511467. Pubmed Central PMCID: 3916760

15. Gangopadhyay S, Nandy A, Hor P, Mukhopadhyay A. Breast cancer stem cells: a novel therapeutic target. Clin Breast Cancer. 2013;13(1):7-15. PubMed PMID: 23127340

16. de Beca FF, Caetano P, Gerhard R, Alvarenga CA, Gomes M, Paredes J, et al. Cancer stem cells markers CD44, CD24 and ALDH1 in breast cancer special histological types. J Clin Pathol. 2013;66(3):187-91. PubMed PMID: 23112116

17. Azzam DJ, Zhao D, Sun J, Minn AJ, Ranganathan P, Drews-Elger K, et al. Triple negative breast cancer initiating cell subsets differ in functional and molecular characteristics and in gamma-secretase inhibitor drug responses. EMBO Mol Med. 2013;5(10):1502-22. PubMed PMID: 23982961. Pubmed Central PMCID: 3799576

18. Zhang Y, Yao F, Yao X, Yi C, Tan C, Wei L, et al. Role of CCL5 in invasion, proliferation and proportion of CD44+/CD24- phenotype of MCF-7 cells and correlation of CCL5 and CCR5 expression with breast cancer progression. Oncol Rep. 2009:21(4):1113-21. PubMed PMID: 19288016

19. Wang Z, Butner JD, Kerketta R, Cristini V, Deisboeck TS. Simulating cancer growth with multiscale agent-based modeling. Semin Cancer Biol. 2015:30: 70-8. PubMed PMID: 24793698. Pubmed Central PMCID: 4216775

20. Finley SD, Chu L-H, Popel AS. Computational systems biology approaches to anti-angiogenic cancer therapeutics. Drug Discov Today. 2015;20(2):187-97.

21. Michor F, Beal K. Improving cancer treatment via mathematical modeling: surmounting the challenges is worth the effort. Cell. 2015;163(5):1059-63. PubMed PMID: 26590416. Pubmed Central PMCID: 4676401

22. Altrock PM, Liu LL, Michor F. The mathematics of cancer: integrating quantitative models. Nat Rev Cancer. 2015;15(12):730-45. PubMed PMID: 26597528

23. Enderling $\mathrm{H}$, Rejniak KA. Simulating cancer: computational models in oncology. Frontiers in oncology. 2013;3.

24. Chakrabarti A, Verbridge S, Stroock AD, Fischbach C, Varner JD. Multiscale models of breast cancer progression. Ann Biomed Eng. 2012;40(11):2488-500. PubMed PMID: 23008097. Pubmed Central PMCID: 3868441

25. Franks SJ, Byrne HM, Underwood JC, Lewis CE. Biological inferences from a mathematical model of comedo ductal carcinoma in situ of the breast. J Theor Biol. 2005:232(4):523-43. PubMed PMID: 15588633

26. Rejniak KA. An immersed boundary framework for modelling the growth of individual cells: an application to the early tumour development. J Theor Biol. 2007;247(1):186-204. PubMed PMID: 17416390

27. Rejniak KA, Anderson AR. A computational study of the development of epithelial acini: II. Necessary conditions for structure and lumen stability. Bull Math Biol. 2008;70(5):1450-79. PubMed PMID: 18401665. Pubmed Central PMCID: 3812684

28. Rejniak KA, Anderson AR. A computational study of the development of epithelial acini: I. Sufficient conditions for the formation of a hollow structure. Bull Math Biol. 2008;70(3):677-712. PubMed PMID: 18188652 Pubmed Central PMCID: 3812693

29. Macklin $P$, Edgerton ME, Thompson AM, Cristini V. Patient-calibrated agentbased modelling of ductal carcinoma in situ (DCIS): from microscopic measurements to macroscopic predictions of clinical progression. J Theor Biol. 2012;301:122-40. PubMed PMID: 22342935. Pubmed Central PMCID: 3322268

30. Frieboes HB, Edgerton ME, Fruehauf JP, Rose FR, Worrall LK, Gatenby RA, et al. Prediction of drug response in breast cancer using integrative experimental/computational modeling. Cancer Res. 2009:69(10):4484-92. PubMed PMID: 19366802. Pubmed Central PMCID: 2720602

31. Boghaert E, Radisky DC, Nelson CM. Lattice-based model of ductal carcinoma in situ suggests rules for breast cancer progression to an invasive state. PLoS Comput Biol. 2014;10(12):e1003997. PubMed PMID: 25473842. Pubmed Central PMCID: 4256017

32. Radisky DC, Nelson CM. Regulation of mechanical stress by mammary epithelial tissue structure controls breast cancer cell invasion. Oncotarget. 2013;4(4):498-9. PubMed PMID: 23625757. Pubmed Central PMCID: 3720598

33. Kim M, Gillies RJ, Rejniak KA. Current advances in mathematical modeling of anti-cancer drug penetration into tumor tissues. Front Oncol. 2013;3:278 PubMed PMID: 24303366. Pubmed Central PMCID: 3831268

34. Macklin P, Mumenthaler S, Lowengrub J. Modeling multiscale necrotic and calcified tissue biomechanics in cancer patients: application to Ductal carcinoma in situ (DCIS). In: Gefen A, editor. Multiscale computer modeling in biomechanics and biomedical engineering. Berlin, Heidelberg: Springer Berlin Heidelberg; 2013. p. 349-80. 
35. Norton KA, Wininger M, Bhanot G, Ganesan S, Barnard N, Shinbrot T. A 2D mechanistic model of breast ductal carcinoma in situ (DCIS) morphology and progression. J Theor Biol. 2010;263(4):393-406. PubMed PMID: 20006623. Pubmed Central PMCID: 2839055

36. Norton KA, Popel AS. An agent-based model of cancer stem cell initiated avascular tumour growth and metastasis: the effect of seeding frequency and location. J R Soc Interface. 2014;11(100):20140640. PubMed PMID: 25185580. Pubmed Central PMCID: 4191089

37. Norton KA, Popel AS. Effects of endothelial cell proliferation and migration rates in a computational model of sprouting angiogenesis. Sci Rep. 2016;6: 36992. PubMed PMID: 27841344. Pubmed Central PMCID: 5107954

38. Poleszczuk J, Macklin P, Enderling H. Agent-based modeling of cancer stem cell driven solid tumor growth. Totowa, NJ: Humana Press. 2016;1-12.

39. Enderling $H$, Chaplain MA, Hahnfeldt P. Quantitative modeling of tumor dynamics and radiotherapy. Acta Biotheor. 2010;58(4):341-53. PubMed PMID: 20658170

40. Enderling H, Hlatky L, Hahnfeldt P. Tumor morphological evolution: directed migration and gain and loss of the self-metastatic phenotype. Biol Direct. 2010:5:23. PubMed PMID: 20406441. Pubmed Central PMCID: 2868833

41. Enderling $H$, Hlatky L, Hahnfeldt P. Immunoediting: evidence of the multifaceted role of the immune system in self-metastatic tumor growth. Theor Biol Med Model. 2012;9:31. PubMed PMID: 22838395. Pubmed Central PMCID: 3499182

42. Enderling H, Hahnfeldt $P$, Hlatky L, Almog N. Systems biology of tumor dormancy: linking biology and mathematics on multiple scales to improve cancer therapy. Cancer Res. 2012;72(9):2172-5. PubMed PMID: 22414579. Pubmed Central PMCID: 3374524

43. Poleszczuk J, Hahnfeldt $\mathrm{P}$, Enderling $\mathrm{H}$. Biphasic modulation of cancer stem cell-driven solid tumour dynamics in response to reactivated replicative senescence. Cell Prolif. 2014:47(3):267-76. PubMed PMID: 24666838

44. Enderling $H$, Hahnfeldt P. Cancer stem cells in solid tumors: is 'evading apoptosis' a hallmark of cancer? Prog Biophys Mol Biol. 2011;106(2):391-9. PubMed PMID: 21473880

45. Sottoriva A, Verhoeff JJ, Borovski T, McWeeney SK, Naumov L, Medema JP, et al. Cancer stem cell tumor model reveals invasive morphology and increased phenotypical heterogeneity. Cancer Res. 2010;70(1):46-56. PubMed PMID: 20048071

46. Haeno H, Gonen M, Davis MB, Herman JM, lacobuzio-Donahue CA, Michor F. Computational modeling of pancreatic cancer reveals kinetics of metastasis suggesting optimum treatment strategies. Cell. 2012; 148(1-2):362-75. PubMed PMID: 22265421. Pubmed Central PMCID: 3289413

47. Leder K, Pitter K, Laplant Q, Hambardzumyan D, Ross BD, Chan TA, et al. Mathematical modeling of PDGF-driven glioblastoma reveals optimized radiation dosing schedules. Cell. 2014;156(3):603-16. PubMed PMID: 24485463. Pubmed Central PMCID: 3923371

48. Foo J, Liu LL, Leder K, Riester M, Iwasa Y, Lengauer C, et al. An evolutionary approach for identifying driver mutations in colorectal cancer. PLoS Comput Biol. 2015;11(9):e1004350. PubMed PMID: 26379039. Pubmed Central PMCID: 4575033

49. Kareva I. Immune evasion through competitive inhibition: the shielding effect of cancer non-stem cells. J Theor Biol. 2015;364:40-8. PubMed PMID: 25195001

50. Beca F, Polyak K. Intratumor heterogeneity in breast cancer. Adv Exp Med Biol. 2016;882:169-89. PubMed PMID: 26987535

51. Polyak K. Heterogeneity in breast cancer. J Clin Invest. 2011;121(10):3786-8. PubMed PMID: 21965334. Pubmed Central PMCID: 3195489

52. Stingl J, Caldas C. Molecular heterogeneity of breast carcinomas and the cancer stem cell hypothesis. Nat Rev Cancer. 2007;7(10):791-9. PubMed PMID: 17851544

53. Pohlman S, Powell KA, Obuchowski NA, Chilcote WA, GrundfestBroniatowski S. Quantitative classification of breast tumors in digitized mammograms. Med Phys. 1996;23(8):1337-45. PubMed PMID: 8873030

54. El-Faramawy N, Rangayyan R, Desautels J, Alim O, editors. Shape factors for analysis of breast tumors in mammograms. Electrical and Computer Engineering, 1996 Canadian Conference on; 1996: Calgary; IEEE.

55. Baish JW, Jain RK. Fractals and cancer. Cancer Res. 2000;60(14):3683-8. PubMed PMID: 10919633

56. Song $H$, Hedayati M, Hobbs RF, Shao C, Bruchertseifer F, Morgenstern A, et al. Targeting aberrant DNA double-strand break repair in triple-negative breast cancer with alpha-particle emitter radiolabeled anti-EGFR antibody.
Mol Cancer Ther. 2013;12(10):2043-54. PubMed PMID: 23873849. Pubmed Central PMCID: 3804319

57. Peela N, Sam FS, Christenson W, Truong D, Watson AW, Mouneimne G, et al. A three dimensional micropatterned tumor model for breast cancer cell migration studies. Biomaterials. 2016;81:72-83. PubMed PMID: 26724455

58. Poincloux R, Collin O, Lizarraga F, Romao M, Debray M, Piel M, et al. Contractility of the cell rear drives invasion of breast tumor cells in 3D Matrigel. Proc Natl Acad Sci U S A. 2011;108(5):1943-8. PubMed PMID: 21245302. Pubmed Central PMCID: 3033302

59. Stroka KM, Jiang H, Chen S-H, Tong Z, Wirtz D, Sun SX, et al. Water permeation drives tumor cell migration in confined microenvironments. Cell. 2014;157(3):611-23.

60. Wang S-J, Saadi W, Lin F, Nguyen CM-C, Jeon NL. Differential effects of EGF gradient profiles on MDA-MB-231 breast cancer cell chemotaxis. Exp Cell Res. 2004;300(1):180-9.

61. Yang S, Zhang JJ, Huang X-Y. Orai1 and STIM1 are critical for breast tumor cell migration and metastasis. Cancer Cell. 2009;15(2):124-34.

62. Lin S, Wan S, Sun L, Hu J, Fang D, Zhao R, et al. Chemokine C-C motif receptor 5 and $\mathrm{C}-\mathrm{C}$ motif ligand 5 promote cancer cell migration under hypoxia. Cancer Sci. 2012;103(5):904-12. PubMed PMID: 22380870

63. Norton BL, Hicks CB. Maraviroc: the first chemokine coreceptor 5 inhibitor. Futur Virol. 2011:6(3):283-94.

64. Gillies RJ, Gatenby RA. Adaptive landscapes and emergent phenotypes: why do cancers have high glycolysis? J Bioenerg Biomembr. 2007;39(3):251-7. PubMed PMID: 17624581

65. Iftekharuddin KM, Jia W, Marsh R. Fractal analysis of tumor in brain MR images. Mach Vis Appl. 2003;13(5-6):352-62

66. Mansury Y, Deisboeck TS. Simulating 'structure-function'patterns of malignant brain tumors. Phys Stat Mech Appl. 2004;331(1):219-32

67. Nyirenda N, Farkas DL, Ramanujan VK. Preclinical evaluation of nuclear morphometry and tissue topology for breast carcinoma detection and margin assessment. Breast Cancer Res Treat. 2011;126(2):345-54. PubMed PMID: 20446030. Pubmed Central PMCID: 2982889

68. Korkaya H, Liu S, Wicha MS. Breast cancer stem cells, cytokine networks, and the tumor microenvironment. J Clin Invest. 2011;121(10):3804-9. PubMed PMID: 21965337. Pubmed Central PMCID: 3223613

69. Norton KA, Popel AS, Pandey NB. Heterogeneity of chemokine cell-surface receptor expression in triple-negative breast cancer. Am J Cancer Res. 2015;5(4):1295-307. PubMed PMID: 26101698. Pubmed Central PMCID: 4473311

70. Waclaw B, Bozic I, Pittman ME, Hruban RH, Vogelstein B, Nowak MA. A spatial model predicts that dispersal and cell turnover limit intratumour heterogeneity. Nature. 2015;525(7568):261-4. PubMed PMID: 26308893. Pubmed Central PMCID: 4782800

71. Pellegrini P, Dyczynski M, Sbrana FV, Karlgren M, Buoncervello M, HaggOlofsson $M$, et al. Tumor acidosis enhances cytotoxic effects and autophagy inhibition by salinomycin on cancer cell lines and cancer stem cells. Oncotarget. 2016;7(24):35703-23. PubMed PMID: 27248168

72. Vidal SJ, Rodriguez-Bravo V, Galsky M, Cordon-Cardo C, Domingo-Domenech J. Targeting cancer stem cells to suppress acquired chemotherapy resistance. Oncogene. 2014;33(36):4451-63. PubMed PMID: 24096485

73. Lamb R, Harrison H, Smith DL, Townsend PA, Jackson T, Ozsvari B, et al. Targeting tumor-initiating cells: eliminating anabolic cancer stem cells with inhibitors of protein synthesis or by mimicking caloric restriction. Oncotarget. 2015;6(7):4585-601. PubMed PMID: 25671304. Pubmed Central PMCID: 4467101

74. Vaupel $P$, Mayer A. Hypoxia in cancer: significance and impact on clinical outcome. Cancer Metastasis Rev. 2007;26(2):225-39.

75. Hu K, Babapoor-Farrokhran S, Rodrigues M, Deshpande M, Puchner B, Kashiwabuchi F, et al. Hypoxia-inducible factor 1 upregulation of both VEGF and ANGPTL4 is required to promote the angiogenic phenotype in uveal melanoma. Oncotarget. 2016;7816.

76. Konecny GE, Meng YG, Untch M, Wang HJ, Bauerfeind I, Epstein M, et al. Association between HER-2/neu and vascular endothelial growth factor expression predicts clinical outcome in primary breast cancer patients. Clin Cancer Res. 2004;10(5):1706-16. PubMed PMID: 15014023

77. Schindl M, Schoppmann SF, Samonigg H, Hausmaninger $H$, Kwasny W, Gnant M, et al. Overexpression of hypoxia-inducible factor 1alpha is associated with an unfavorable prognosis in lymph node-positive breast cancer. Clin Cancer Res. 2002;8(6):1831-7. PubMed PMID: 12060624 
78. Rankin EB, Giaccia AJ. The role of hypoxia-inducible factors in tumorigenesis. Cell Death Differ. 2008;15(4):678-85. PubMed PMID: 18259193. Pubmed Central PMCID: 3050610

79. Chen J, Imanaka N, Chen J, Griffin JD. Hypoxia potentiates notch signaling in breast cancer leading to decreased E-cadherin expression and increased cell migration and invasion. Br J Cancer. 2010;102(2):351-60. PubMed PMID: WOS:000273728500015. English

80. Semenza GL. Cancer-stromal cell interactions mediated by hypoxiainducible factors promote angiogenesis, lymphangiogenesis, and metastasis. Oncogene. 2013;32(35):4057-63. PubMed PMID: 23222717. Pubmed Central PMCID: 4415159

81. Wong CC, Zhang H, Gilkes DM, Chen J, Wei H, Chaturvedi P, et al. Inhibitors of hypoxia-inducible factor 1 block breast cancer metastatic niche formation and lung metastasis. J Mol Med (Berl). 2012;90(7):803-15. PubMed PMID: 22231744. Pubmed Central PMCID: 3437551

82. Mu Z, Jiao X, Pestell RG, Cristofanilli M. Abstract P6-14-06: CCR5 antagonists suppresses the migration and invasion of human inflammatory breast cancer cells. Cancer Res. 2015;75(9 Supplement):P6-14-06. P6-14-06

83. Qiu M, Peng QH, Jiang I, Carroll C, Han GZ, Rymer I, et al. Specific inhibition of Notch1 signaling enhances the antitumor efficacy of chemotherapy in triple negative breast cancer through reduction of cancer stem cells. Cancer Lett. 2013:328(2):261-70. PubMed PMID: WOS:000313138000010. English

84. Liu P, Kumar IS, Brown S, Kannappan V, Tawari PE, Tang JZ, et al. Disulfiram targets cancer stem-like cells and reverses resistance and cross-resistance in acquired paclitaxel-resistant triple-negative breast cancer cells. Br J Cancer. 2013;109(7):1876-85. PubMed PMID: 24008666. Pubmed Central PMCID: 3790184

85. Samanta D, Gilkes DM, Chaturvedi P, Xiang L, Semenza GL. Hypoxiainducible factors are required for chemotherapy resistance of breast cancer stem cells. Proc Natl Acad Sci U S A. 2014;111(50):E5429-38. PubMed PMID: 25453096. Pubmed Central PMCID: 4273385

86. Korkaya H, Paulson A, lovino F, Wicha MS. HER2 regulates the mammary stem/progenitor cell population driving tumorigenesis and invasion. Oncogene. 2008;27(47):6120-30. PubMed PMID: 18591932. Pubmed Central PMCID: 2602947

87. Charafe-Jauffret E, Ginestier C, Bertucci F, Cabaud O, Wicinski J, Finetti P, et al. ALDH1-positive cancer stem cells predict engraftment of primary breast tumors and are governed by a common stem cell program. Cancer Res. 2013;73(24):7290-300. PubMed PMID: 24142344

88. Xiang LS, Gilkes DM, Chaturvedi P, Luo WB, Hu HX, Takano N, et al. Ganetespib blocks HIF-1 activity and inhibits tumor growth, vascularization, stem cell maintenance, invasion, and metastasis in orthotopic mouse models of triple-negative breast cancer. J Mol Med-Jmm. 2014;92(2):151-64. PubMed PMID: WOS:000330980000006. English

89. Fillmore CM, Kuperwasser C. Human breast cancer cell lines contain stemlike cells that self-renew, give rise to phenotypically diverse progeny and survive chemotherapy. Breast Cancer Research. 2008;10(2):R25. PubMed PMID: WOS:000255941100013. English.

90. Peeters MC, Fokkelman M, Boogaard B, Egerod KL, van de Water B, IJ AP, et al. The adhesion $G$ protein-coupled receptor G2 (ADGRG2/GPR64) constitutively activates SRE and NFkappaB and is involved in cell adhesion and migration. Cell Signal. 2015;27(12):2579-88. PubMed PMID: 26321231

91. Provenzano PP, Inman DR, Eliceiri KW, Trier SM, Keely PJ. Contact guidance mediated three-dimensional cell migration is regulated by rho/ROCKdependent matrix reorganization. Biophys J. 2008;95(11):5374-84.

92. Meyer AS, Hughes-Alford SK, Kay JE, Castillo A, Wells A, Gertler FB, et al. 2D protrusion but not motility predicts growth factor-induced cancer cell migration in 3D collagen. J Cell Biol. 2012;197(6):721-9.

\section{Submit your next manuscript to BioMed Central and we will help you at every step:}

- We accept pre-submission inquiries

- Our selector tool helps you to find the most relevant journal

- We provide round the clock customer support

- Convenient online submission

- Thorough peer review

- Inclusion in PubMed and all major indexing services

- Maximum visibility for your research

Submit your manuscript at www.biomedcentral.com/submit
Biomed Central 